\title{
Mobile application analysis and design with geolocation and data from hospitals near home
}

\author{
Alexi Delgado ${ }^{1}$, Asuncion Natalia Caballero-Bedon $^{2}$, Chiara Carbajal $^{3}$ \\ ${ }^{1}$ Mining Engineering Section, Pontificia Universidad Católica del Perú, Lima-Peru, kdelgadov@ pucp.edu.pe \\ ${ }^{2}$ Systems Engineering Program, Universidad de Ciencias y Humanidades, Lima-Peru, asucaballerob@uch.pe \\ ${ }^{3}$ Administration Program, Universidad de Ciencias y Humanidades, Lima-Peru, ccarbajal@uch.edu.pe
}

\begin{abstract}
Nowadays, the problem that has affected thousands of people is that of not being able to locate a nearby health establishment or having information such as telephones or schedules, making it very difficult to go to the aforementioned place. Facing this problem, the present work implemented the Scrum methodology to enable the delivery of this information satisfactorily to the client through a mobile application. For this purpose, a prototype of the application was developed in balsamiq mockup, where its characteristics were explained step by step. In addition, the results obtained based on the methodology and the case study were presented. Finally, the results obtained in the paper could be a guide for some future projects.
\end{abstract}

Key words : Balsamiq mockup, Mobile Application, Scrum.

\section{INTRODUCTION}

Currently, the problem that affects most people today is that of not being able to find a nearby hospital, as well as being unable to identify the specialties offered by that hospital, telephone number, hours, among others [1]. This affects the elderly population, as paradoxically, although it is one of the social groups that most needs this information, it is also the group that is most unfamiliar [2]. However, this problem does not only affect the older population, as it is also observed that in our daily lives, the majority of people do not know the location of hospitals or have erroneous information about them; this becomes even more serious if there is an emergency, since it makes it difficult to contact a transport provider rapidly [3].

Confronted with this problem, it has been considered the possibility of choosing different methodologies such as Extreme Programing, FDD or Kan Ban, which have their own development for agility and development of good quality software [4]. However, the choice of the Scrum methodology has been determined to be appropriate, considering that it possesses the qualities already mentioned [5]. In addition, it will allow us to improve the project and deliver the quality of the software that will be provided to the client, since it allows an adequate organization that will benefit the quality of the work for the final user, achieving also, that the present research is innovative as possible [6], [7].

Therefore, as regards the application, the steps described in the Scrum methodology [8] will be used, with the objective that the present research will be developed in the most understandable way if there is some inexperienced reader in the subject. Likewise, the Balsamiq Mockup tool will be used to describe the development of the mobile application in conjunction with the visualization that the client will have [9]. Therefore, the objective of this research is to present a solution that allows the user population to be informed about the basic requirements that should be known about nearby hospitals in their area.

The methodology chosen for this study together with a brief explanation of the processes is presented in section 2. Then, the corresponding application of the methodology to the proposed purposes is found in section 3. Following this, the results and discussions obtained from the present research will be described in section 4. Finally, the conclusions of the study will be developed in section 5 .

\section{METHODOLOGY}

In the present work the steps for the development of a mobile application will be explained, using the Scrum methodology [10].

\subsection{Scrum Methodology}

There is a process for the realization of the treated project which consists of some steps shown in Figure 1 [11].

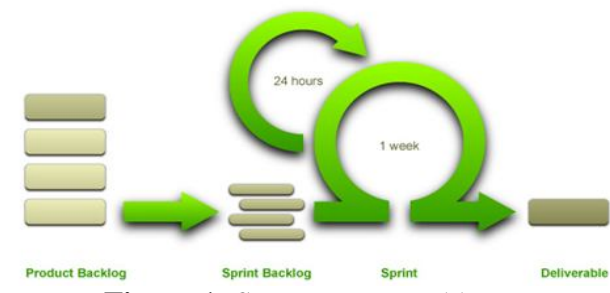

Figure 1: Scrum Process [11]

\section{A. Product Backlog}

In this first stage, all the requirements are met, also referred to as stories, which are prioritized for the benefit of the business [12]. 
Alexi Delgado et al., International Journal of Emerging Trends in Engineering Research, 8(8), August 2020, 4555 - 4559

\section{B. Sprint Backlog}

In this second process, a list of necessary activities or tasks is drawn up with the aim of enabling them to be carried out as effectively as possible.

\section{Daily Sprint meeting}

The third process is the daily meeting that the team conducts, this lasts a maximum of 15 minutes, in addition to this comments are made about the tasks that were done the previous day, what will be done the same day and what impediments exist.

\section{Demo and retrospective}

The fourth process is also a meeting that will take place at the end of each sprint and is the presentation of all the stories of users of the product. In addition, the project team will have to analyze what was done well, what can be improved and what are the obstacles to the perfection of the product [13].

\subsection{Balsamiq Mockups}

This is a tool, which is in charge of making a simulation or a prototype of how a web page or a mobile application may look like. This tool is key as it helps us to see how the project may look in the future [14].

\section{APPLICATION}

Table 1 shows the incremental model, which will be used for the mobile application development. In addition, it explains in detail each one of them, and how the functionality within the mobile application will be.

Table 1: Incremental Model Description

\begin{tabular}{|c|l|}
\hline Increment & \multicolumn{1}{|c|}{ Specification } \\
\hline User control & User will be registered in the login. \\
\hline Locate district & $\begin{array}{l}\text { User will locate the district where he or } \\
\text { she is located. }\end{array}$ \\
\hline Locate hospital & User will locate the nearest hospital. \\
\hline Locate mobility & User will locate the mobility. \\
\hline $\begin{array}{c}\text { Hospital } \\
\text { Information }\end{array}$ & $\begin{array}{l}\text { User will have access to hospital } \\
\text { information. }\end{array}$ \\
\hline $\begin{array}{c}\text { Specialty and } \\
\text { Doctor Information }\end{array}$ & $\begin{array}{l}\text { User will have access to the specialties } \\
\text { and doctors who are in that hospital. }\end{array}$ \\
\hline
\end{tabular}

\subsection{Scrum Methodology}

The Scrum methodology will help the mobile application approach, as it maintains a relationship with the client.

\section{A. Product Backlog}

Table 2 shows the description of each increase to be developed.
Table 2: Increase Description

\begin{tabular}{|c|l|}
\hline Sprint & \multicolumn{1}{|c|}{ Requirements } \\
\hline User control & $\begin{array}{l}\text { There is a need for the user in order to register } \\
\text { their information and save his/her profile. }\end{array}$ \\
\hline $\begin{array}{c}\text { Locate } \\
\text { district }\end{array}$ & $\begin{array}{l}\text { The user needs to be able to register his or her } \\
\text { location to obtain more accurate information. }\end{array}$ \\
\hline $\begin{array}{c}\text { Locate } \\
\text { hospital }\end{array}$ & $\begin{array}{l}\text { It is essential to be able to determine the } \\
\text { nearest hospital based on the location recorded } \\
\text { in the previous step. }\end{array}$ \\
\hline $\begin{array}{c}\text { Locate } \\
\text { mobility }\end{array}$ & $\begin{array}{l}\text { There is a requirement to be able to determine } \\
\text { which the most accessible mobility for the } \\
\text { health center is. }\end{array}$ \\
\hline $\begin{array}{c}\text { Hospital } \\
\text { Information }\end{array}$ & $\begin{array}{l}\text { In order to be able to determine which health } \\
\text { center is the most convenient, the user should } \\
\text { be provided with information that helps } \\
\text { determine this decision such as schedule, } \\
\text { distance, etc. }\end{array}$ \\
\hline $\begin{array}{c}\text { Specialty } \\
\text { and Doctor } \\
\text { Information }\end{array}$ & $\begin{array}{l}\text { Additional information should be given to the } \\
\text { user, such as the specialties that are available } \\
\text { in the hospital, the doctors, etc. }\end{array}$ \\
\hline
\end{tabular}

\section{B. Sprint Backlog}

Table 3 lists the tasks that will be programmed according to the user stories that we are performing.

Table 3: Tasks Planning

\begin{tabular}{|l|c|c|c|c|c|}
\hline \multicolumn{1}{|c|}{ Tasks } & M & Tu & W & Th & F \\
\hline App Design & $\mathrm{x}$ & & & & \\
\hline Business plan implementation & & $\mathrm{x}$ & & & \\
\hline Login Encryption information & & $\mathrm{x}$ & & & \\
\hline Encode Health Facilities nearby & & $\mathrm{x}$ & & & \\
\hline $\begin{array}{l}\text { Encode Health Facilities } \\
\text { information }\end{array}$ & & $\mathrm{x}$ & & & \\
\hline $\begin{array}{l}\text { Specialties } \\
\text { codification }\end{array}$ & & $\mathrm{x}$ & & \\
\hline Doctor information coding & & $\mathrm{x}$ & & \\
\hline
\end{tabular}

\section{Daily Sprint meeting}

Table 4 shows the objective of the sprint and also what would be the planning to be able to perform each one of them.

Table 4: Progressive Sprint Planning

\begin{tabular}{|c|c|c|c|}
\hline Sprint Goals & Pending & In Progress & Complete \\
\hline \multirow{3}{*}{$\begin{array}{l}\text { Enable all } \\
\text { essential parts } \\
\text { of the mobile } \\
\text { application to } \\
\text { allow users to } \\
\text { experience a } \\
\text { fullconsultation } \\
\text { process. }\end{array}$} & $\mathrm{X}$ & User control & $\mathrm{X}$ \\
\hline & $\begin{array}{l}\text { Locate district } \\
\text { Locate hospital } \\
\text { Locate mobility }\end{array}$ & $\mathrm{X}$ & $\mathrm{X}$ \\
\hline & $\begin{array}{c}\text { Hospital } \\
\text { Information } \\
\text { Specialty and } \\
\text { Doctor } \\
\text { Information }\end{array}$ & $\mathrm{X}$ & $\mathrm{X}$ \\
\hline
\end{tabular}




\section{Demo and retrospective}

Table 5 shows the critical questions to be asked at the end of the project, in order to evaluate whether the application was carried out as expected, whether there were any unexpected events and whether an improvement can be implemented for the future.

Table 5: Feedback according to Sprints

\begin{tabular}{|c|c|c|}
\hline $\begin{array}{c}\text { What went well } \\
\text { in the } \\
\text { interaction? }\end{array}$ & $\begin{array}{c}\text { What came out } \\
\text { wrong in the } \\
\text { interaction? }\end{array}$ & $\begin{array}{c}\text { What } \\
\text { improvements } \\
\text { could we make in } \\
\text { the next } \\
\text { interaction? }\end{array}$ \\
\hline User stories & Tasks by sprint & $\begin{array}{c}\text { Sprint and tasks } \\
\text { by each. }\end{array}$ \\
\hline
\end{tabular}

\subsection{Balsamiq Mockups}

Figure 2 shows the home page of the application, where the logo of the application can be seen as well as two options for the user: the login and the sign up for the registration if the user is new in the application. Figure 3 shows the login for the user who already has his account activated as well as the possibility of recovering his password in case of forgetting.

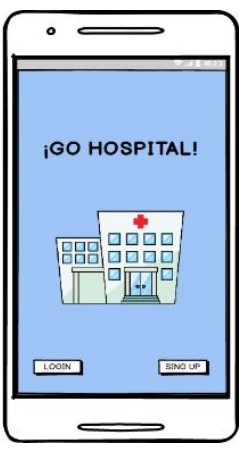

Figure 2: Home Screen

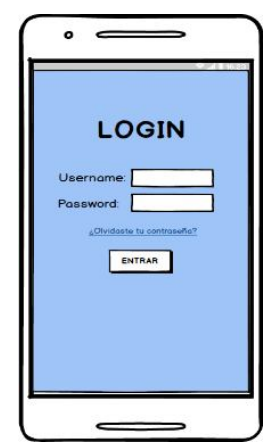

Figure 3:Log in Screen
Figure 4 shows the registration for the user, where he/she will enter his/her main data such as name, last name, email and password. After that, when the user enters the application, the option of being able to locate the nearest hospital will appear as shown in Figure 5.

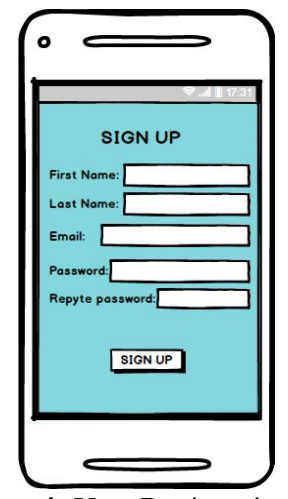

Figure 4: User Registration

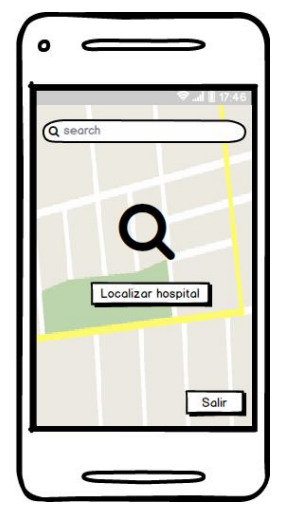

Figure 5:Hospital Finder
The hospitals close to the user are indicated as illustrated in
Figure 6. And when clicking on a hospital the information of the hospital is displayed as visualized in Figure 7.

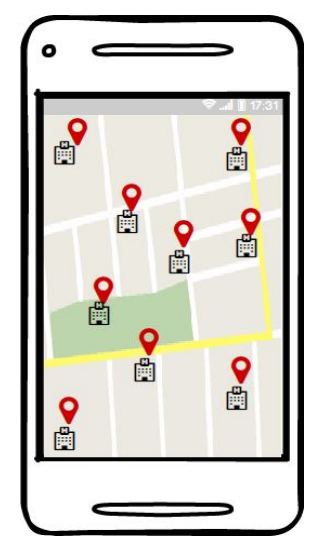

Figure 6: Hospitals Located

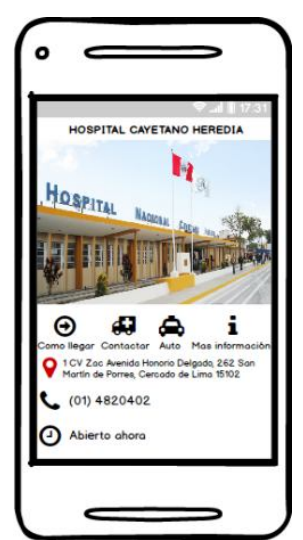

Figure 7:Hospital Information
In addition, the specialties of the hospital of choice are shown, as can be seen in Figure 8. Clicking on any of them will show the information, followed by Figure 9 which shows how the information of those doctors working in the area will be provided to the user.

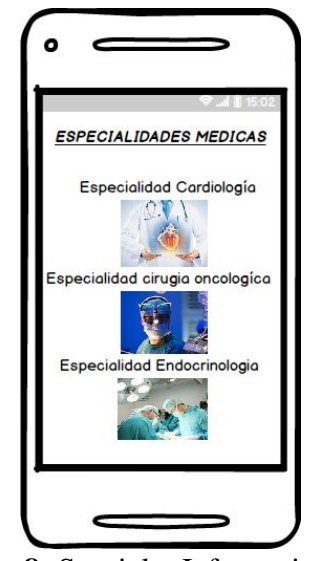

Figure 8: Specialty Information

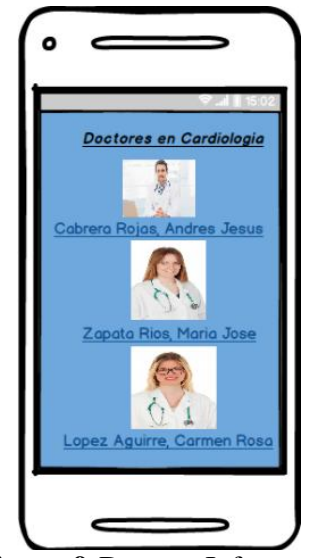

Figure 9:Doctors Information

\section{RESULTS AND DISCUSSION}

\subsection{About the Case Study}

A. Product Backlog

Table 6 verifies whether we are complying with the product backlog according to the increases we have made.

Table 6: Results according to Sprints

\begin{tabular}{|c|l|}
\hline Sprint & \multicolumn{1}{c|}{ Results } \\
\hline User control & $\begin{array}{l}\text { As shown in Figure 3. A username and } \\
\text { password have been highlighted, and in the } \\
\text { case of wanting to register, the corresponding } \\
\text { data must be filled in to proceed to the login, } \\
\text { as shown in Figure 4. }\end{array}$ \\
\hline $\begin{array}{l}\text { Locate } \\
\text { district }\end{array}$ & $\begin{array}{l}\text { As soon as you enter the mobile application, } \\
\text { you will have to choose the district where you } \\
\text { are located. }\end{array}$ \\
\hline Locate & At this stage the user will have the option of \\
\hline
\end{tabular}




\begin{tabular}{|c|l|}
\hline hospital & $\begin{array}{l}\text { being able to locate nearby hospitals, as } \\
\text { shown in Figure 5. }\end{array}$ \\
\hline $\begin{array}{c}\text { Locate } \\
\text { mobility }\end{array}$ & $\begin{array}{l}\text { In this step of the application, the user can } \\
\text { acquire a mobility, in order to go to the } \\
\text { hospital of his/her choice. }\end{array}$ \\
\hline $\begin{array}{c}\text { Hospital } \\
\text { Information }\end{array}$ & $\begin{array}{l}\text { This will give the user access to the hospital } \\
\text { information, as shown in Figure 8, it will } \\
\text { provide schedule, phone number, location. }\end{array}$ \\
\hline $\begin{array}{c}\text { Specialty and } \\
\text { Doctor } \\
\text { Information }\end{array}$ & $\begin{array}{l}\text { In this step we will present the specialties that } \\
\text { each hospital has, as shown in Figure 9. In } \\
\text { addition, we will be able to verify which } \\
\text { doctors work in each specialty. }\end{array}$ \\
\hline
\end{tabular}

\section{B. Sprint Backlog}

In Table 7 we verify the results of the tasks, which we have proposed for the realization of the mobile application.

Table 7: Results according to Tasks

\begin{tabular}{|c|l|}
\hline Tasks & \multicolumn{1}{|c|}{ Results } \\
\hline App Design & $\begin{array}{l}\text { The application is currently up to 90\% } \\
\text { designed for customer satisfaction. }\end{array}$ \\
\hline $\begin{array}{c}\text { Business plan } \\
\text { implementation }\end{array}$ & $\begin{array}{l}\text { A business plan provides customer } \\
\text { service, which is being successfully } \\
\text { executed in this project. }\end{array}$ \\
\hline $\begin{array}{c}\text { Login } \\
\text { Encryption }\end{array}$ & $\begin{array}{l}\text { No code has been implemented yet, only a } \\
\text { demo was developed in Balsamiq mockup. }\end{array}$ \\
\hline $\begin{array}{c}\text { Encode Health } \\
\text { Facilities nearby }\end{array}$ & $\begin{array}{l}\text { It was introduced that when the user's } \\
\text { location was tracked, the hospitals close to } \\
\text { the user were monitored. }\end{array}$ \\
\hline $\begin{array}{c}\text { Encode Health } \\
\text { Facilities } \\
\text { information }\end{array}$ & $\begin{array}{l}\text { All types of hospital information were } \\
\text { implemented for users who enter the } \\
\text { mobile application. }\end{array}$ \\
\hline
\end{tabular}

\section{Daily Sprint meeting}

Table 8 verifies the daily planning of the sprint, whether it is to be developed, in process or completed, as noted all sprint are already made and others are in progress, this in order to perfect the application.

Table 8: Results according to Sprints Planning

\begin{tabular}{|l|c|c|c|}
\hline \multicolumn{1}{|c|}{$\begin{array}{c}\text { Sprint } \\
\text { Goals }\end{array}$} & Pending & In Progress & Complete \\
\hline $\begin{array}{l}\text { Enable all } \\
\text { essential } \\
\text { parts of the } \\
\text { mobile } \\
\text { application } \\
\text { to allow } \\
\text { users to } \\
\text { experience a } \\
\text { full } \\
\text { consultation } \\
\text { process. }\end{array}$ & $\mathrm{x}$ & $\mathrm{x}$ & $\begin{array}{c}\text { User } \\
\text { control }\end{array}$ \\
\cline { 2 - 4 } & $\mathrm{x}$ & $\begin{array}{c}\text { Locate district } \\
\text { Locate hospital } \\
\text { Locate mobility }\end{array}$ & $\mathrm{x}$ \\
\hline
\end{tabular}

\section{Demo and retrospective}

In Table 9 we will verify everything that has been done and that has gone well, in addition to it, it is mandatory that we will evaluate if there has been some problem or difficulty to achieve the goals of the study and finally what we will improve, so the application goes optimally.

Table 9: Feedback Results

\begin{tabular}{|c|c|c|}
\hline $\begin{array}{c}\text { What went well } \\
\text { in the } \\
\text { interaction? }\end{array}$ & $\begin{array}{c}\text { What came out } \\
\text { wrong in the } \\
\text { interaction? }\end{array}$ & $\begin{array}{c}\text { What } \\
\text { improvements } \\
\text { could we make in } \\
\text { the next } \\
\text { interaction? }\end{array}$ \\
\hline $\begin{array}{c}\text { User stories, } \\
\text { Sprint and Sprint } \\
\text { tasks }\end{array}$ & $\begin{array}{c}\text { Balsamiq mockup } \\
\text { tool }\end{array}$ & $\begin{array}{c}\text { it would lack to } \\
\text { finish and to } \\
\text { verify if it fits } \\
\text { well. }\end{array}$ \\
\hline
\end{tabular}

\subsection{About the Methodology}

A. Advantages

- The customer can quickly start using the application.

- The application provided to the customer is of high quality.

- The customer may decide to make changes to his/her satisfaction.

- The process is accelerated, taking small tasks for ease of execution.

\section{B. Disadvantages}

- If the owner of the product is not satisfied with the product, other new tasks will need to be performed to their satisfaction.

- Missing members of the development team.

- Necessity of different multidisciplinary teams can cause time and cost problems.

\section{Comparison}

It has been observed that in comparison with other research studies such as a study concerning the design of a mobile application that measures Ureic Nitrogen [15], the methodology used in this paper proved to be the most accessible and simple to explain to that new reader in the subject. The Scrum methodology explains step by step the realization of the project, as well as the planning of tasks that will be carried out to achieve the proposed objective, allowing also to list a predetermined order that benefits the explanation and the facility to understand it.

\section{CONCLUSIONS}

Regarding the case study, the application was carried out in a way that the user would understand, facilitating its future implementation. Therefore, it is observed that the current study serves as a good foundation for the design of an application that solves the problematic exposed in the introduction, not being able to locate health facilities easily and that the majority of the population is unaware of the subject.

With respect to the Scrum methodology applied, it was demonstrated that it was a beneficial application because it 
allowed to distinguish the user's stories as well as the tasks to be performed, which collaborated in the acceleration of the project.

For future projects related to the issue presented above, it is recommended to cover different points that have not been considered as the possibility of making a reservation in the health facility through the same application. It is also pertinent to point out that the "Balsamiq mockup" tool benefited greatly the study as it allowed the elaboration of an effective first sketch. The continued use of this tool is therefore recommended.

\section{REFERENCES}

1. S. Qiaoyu, S. Qiaoyan, C. Lijuan, and Z. Chuanyun, Application of wireless local area network in hospital information system, in Proceedings of 2017 IEEE 2nd Advanced Information Technology, Electronic and Automation Control Conference, IAEAC 2017, 2017, pp. 263-266.

2. D. Rodionov, K. Bushminkin, and G. Kolev, A cooperative localization technique for tracking in hospitals and nursing homes, in Proceedings - 2013 IEEE International Conference on Healthcare Informatics, ICHI 2013, 2013, pp. 471-475.

3. J. C. Tenas and N. A. Serrat, Calidad de las Web de los Hospitales Privados, in Iberian Conference on Information Systems and Technologies, CISTI, 2016, vol. 2016-July.

4. G. Tamez and C. Gaytán, Metodología de selección de recubrimientos para transformadores eléctricos instalados en ambientes corrosivos extremos, in 2017 IEEE 37th Central America and Panama Convention, CONCAPAN 2017, 2018, vol. 2018-January, pp. 1-6.

5. C. P. Godoy, A. F. Cruz, E. P. Silva, L. M. Santos, R. S. Zerbini, and C. A. L. Pahins, Blueprint Model: A new Approach to Scrum Agile Methodology, in Proceedings - 2019 ACM/IEEE 14th International Conference on Global Software Engineering, ICGSE 2019, 2019, pp. 95-99. https://doi.org/10.1109/ICGSE.2019.00014

6. J. Sutherland, N. Harrison, and J. Riddle, Teams that finish early accelerate faster: A pattern language for high performing scrum teams, in Proceedings of the Annual Hawaii International Conference on System Sciences, 2014, pp. 4722-4728.

7. A. Mundra, S. Misra, and C. A. Dhawale, Practical scrum-scrum team: Way to produce successful and quality software, in Proceedings of the 2013 13th International Conference on Computational Science and Its Applications, ICCSA 2013, 2013, pp. 119-123.

8. A. Srivastava, S. Bhardwaj, and S. Saraswat, SCRUM model for agile methodology, in Proceeding - IEEE International Conference on Computing, Communication and Automation, ICCCA 2017, 2017, vol. 2017-January, pp. 864-869.

9. L. Li, J. S. Li, F. Du, and D. H. Si, Building virtual reality design system based on DIVISION mockup software, in Proceedings - International Conference on Electrical and Control Engineering, ICECE 2010, 2010, pp. 552-555.

10. A. I. Bohmer, P. Hugger, and U. Lindemann, Scrum within hardware development insights of the application of scrum for the development of a passive exoskeleton, in 2017 International Conference on Engineering, Technology and Innovation: Engineering, Technology and Innovation Management Beyond 2020: New Challenges, New Approaches, ICE/ITMC 2017 . Proceedings, 2018, vol. 2018-January, pp. 790-798.

11.S. Nootyaskool and P. Ounsrimuang, Optimization algorithm using scrum process, in Proceedings International Conference on Machine Learning and Cybernetics, 2016, vol. 1, pp. 245-250. https://doi.org/10.1109/ICMLC.2016.7860908

12. S. Zhao and X. Lin, Design of scheduling algorithms for end-to-end backlog minimization in wireless multi-hop networks under K-hop interference models, IEEE/ACM Trans. Netw., vol. 24, no. 2, pp. 1265-1278, Apr. 2016.

13. M. Paasivaara and C. Lassenius, Scaling scrum in a large globally distributed organization: A case study, in Proceedings - 11th IEEE International Conference on Global Software Engineering, ICGSE 2016, 2016, pp. 74-83. https://doi.org/10.1109/ICGSE.2016.34

14. G. Larkou, M. Mintzis, S. Taranto, A. Konstantinidis, P. G. Andreou, and D. Zeinalipour-Yazti, Demonstration Abstract: Sensor Mockup Experiments with SmartLab.

15. G. A. Martínez Chávez, On line mesurement of urea by aplication in Paired Filtration Dialysis (PFD) experience in military hospital center, in Annual International Conference of the IEEE Engineering in Medicine and Biology - Proceedings, 2007, pp. 3528-3531. 